\title{
Learning Devices Based on Realistic Approach to Increase the Ability of Mathematical Literation of Junior High School Students
}

\author{
Zulia Fitriani \\ Mathematic Education Post Graduate \\ Universitas Negeri Medan \\ Medan, Indonesia \\ pkzulia@gmail.com
}

\author{
Hasratuddin \\ Mathematic Education Post Graduate \\ Universitas Negeri Medan \\ Medan, Indonesia \\ siregarhasratuddin@yahoo.com
}

\begin{abstract}
Mathematical literacy is students' ability to analyze, reason, and convey ideas effectively, formulate, solve, and interpret mathematical problems in various forms and situations. The purpose of this study was to analyze the improvement of students' mathematical literacy skills after getting learning using realistic approach-based learning tools and to find effective learning tools based on realistic approaches. This research was conducted on seventh grade junior high school students. The development model used is the 4-D (Define, Design, Develop, and Disseminate) model of Thiagarajan, Semmel and Semmel. The results of this study are improving students' mathematical literacy skills and finding effective learning tools.
\end{abstract} words)

Keywords-component; formatting; style; styling; insert (key

\section{INTRODUCTION}

PISA (Program for International Student Assessment) is a project of the Organization for Economic Co-operation and Development (OECD) designed to evaluate educational outcomes in terms of the ability of 15-year-old students in the fields of mathematics, reading, and science.

In PISA (2012) [1], mathematical literacy focuses on students' ability to analyze, reason, and convey ideas effectively, formulate, solve, and interpret mathematical problems in various forms and situations. The assessment used is to focus on problems in real life, outside of situations or problems that are often discussed in class. In real life, we often face problems when shopping, traveling, cooking, financial problems, analyzing political situations, and other things where the use of quantitative reasoning, spatial, or other mathematical abilities is a tool to explain or solve a problem.

Attitudes and emotions such as confidence, curiosity, feelings of interest and relevance, the desire to do or understand something is not a component of mathematical literacy. However, this is an important prerequisite for mathematical literacy. In principle, one can bring up mathematical literacy skills without displaying attitudes and emotions at the same time. But in practice, it is very rare that mathematical literacy skills are applied and used by someone who does not have a level of confidence, curiosity, a feeling of interest and relevance, and a desire to do or understand something that contains a mathematical component.

Indonesian students' literacy achievements can be seen from the results of Indonesia's participation in several international comparative studies, such as Trends in the International Mathematics and Science Study (TIMSS) and the Program for International Student Assessment (PISA). The results of the TIMSS study which aims to find out the development of mathematics and natural sciences of 13 year old students Junior High School (SMP) / Islamic Junior High School (MTs) have not shown satisfactory achievements. Indonesian students in math skills in 1999 were only able to rank 34 of 38 countries. In 2003 Indonesian students mathematical abilities were ranked 35 th out of 46 countries. Furthermore, in 2007 Indonesian student achievement did not show a significant increase, namely the ability of mathematics to be ranked 36th out of 49 countries (Puspendik, 2012a) [2]. The results of the latest TIMSS in 2011 are also not far away, namely mathematics is ranked 38 of 42 countries (Kemdikbud, Penelitian dan Pengembangan, 2013) [3].

Relatively similar results on students' mathematical literacy can also be seen in the PISA study report. The achievement of Indonesian students' mathematics scores significantly shows that it is below the international average (score 500). In 2000 the 15-year-old Indonesian students mathematical literacy achievement was ranked 39th out of 41 participating countries. Students' mathematical literacy achievement remained low on the PISA held in 2003, which was ranked 38th out of 40 countries, and ranked 50th out of 57 participating countries in 2006 (Puspendik, 2012b) [4] Furthermore, in PISA 2012 the achievement of mathematical literacy of Indonesian students has dropped to rank 64 out of 65 countries. As a comparison, Vietnamese students 'literacy achievement was far better than Indonesia in PISA 2012. The average score of Indonesian students' mathematics achievement was 375 points (OECD, 2013) [5] where almost all Indonesian students only mastered subject matter up to level 3 only from 6 levels, while students in both developed and developing countries master the lessons up to level 4, 5, and even 6 (OECD, 2009) [6]. Stacey (2010) in Delyanti (2014: 75) [7] examines the level of literacy achieved by 
Indonesian students from 2000 to 2009 the level of achievement of Indonesian students' literacy abilities when viewed from the score achieved can only reach under 400 with the ability The highest cognitive average can only reach level 3 and 4. In addition, the exposure of the Minister of Education and Culture, Anies R. Baswedan, Phd, which was conveyed in a Ministry meeting with the Head of Service on 1 December 2014, stated that of the six levels of mathematical competence in PISA that can be achieved by students based on skill level, there are $76 \%$ of Indonesian children in PISA who do not reach level 2, the minimum level to get out of the low achievers category. While the number of children who reached the highest level were level 5 and 6 , only $0.3 \%$. The level of mathematical competence shows the ability of Indonesian students who are still weak in mathematical literacy. The PISA results and the minister's exposure show the low mathematical literacy skills of Indonesian students. Whereas mathematical literacy is in line with the standard content of mathematics subjects in the Indonesian curriculum (Wardono, 2014) [8].

Maybe there is no best and right approach to learning mathematics because all learning approaches have their own strengths and weaknesses, but that does not mean that there is no approach that can make mathematics more attractive so that it can improve students' mathematical literacy skills. In accordance with the definition of mathematical literacy skills described by PISA (2012) where students must be able to solve real problems (real world problems) that require students to use the abilities and competencies they have gained through experience in school and everyday.

It is undeniable, one of the mathematical approaches that is currently being talked about and implemented is a realistic approach which is one of the approaches to learning mathematics that is oriented towards mathematical everyday experiences and applying them in daily life. Realistic mathematics education is strongly influenced by the idea of Hans Freudenthal (1991) [9] namely mathematics as a form of human activity which is a very clear point of view in contrast to mathematics printed in books and embedded in the mind. According to Freudenthal, mathematics must be linked to reality, close to the child's experience and relevant to people's lives, to be a valuable human being. Gravemeijer (1994) [10] proposes three main principles in Realistic Mathematics Education, namely: (a) Guided discovery and progressive mathematics, (b) didactic phenomenology, and (c) own development model.

One of the innovations in improving the quality of education is by developing learning tools. Learning devices are a number of materials, tools, media, instructions and guidelines that will be used in the learning process. According to Ibrahim in Trianto (2009: 201) [11], "the device used in the learning process is called a learning device". Learning tools needed to manage the teaching and learning process can be: syllabus, Learning Implementation Plan (RPP), Student Activity Sheet (LKS), evaluation instruments or Learning Outcomes Tests (THB), as well as student textbooks. Therefore learning devices are very important in teaching and learning activities so that teachers are required to have the ability to design / design their own learning tools so that they can help students achieve learning objectives.

The importance of learning tools is expressed by Suparno (2012: 17) [12]

Before the teacher teaches (the preparation stage) a teacher is expected to prepare materials to be taught, prepare teaching aids / practicum that will be used, prepare questions and direction to lure students to be more active in learning, learn the state of students, understand students' weaknesses and strengths, and learn knowledge the beginning of the student, all of this will be broken down in the learning device.

But in reality designing the ideal, quality and understandable syllabus and RPP is not easy. Sometimes the RPP that has been designed by the teacher is not in accordance with the implementation in the classroom due to the emergence of unexpected student responses. So the teacher must prepare several possibilities that will occur during the teaching and learning process so that the students' responses that appear are not neglected, the teacher must be better prepared to overcome all the possibilities that will occur. The purpose of developing learning tools is to produce a product that can help students in the learning process in the classroom, where the product can achieve the desired learning goals, especially in improving students' mathematical abilities. Therefore, Nieveen (in Hasratuddin, 2015: 151) [13] states that the learning device is said to be quality if it meets aspects: Validity, practicality, and effectiveness.

The development of this learning tool refers to the development research model suggested by Thiagarajan and Semmel (Trianto, 2009) is a 4-D model consisting of 4 stages: Define, Design, Develop, and Desseminate.

\section{METHOD}

This research includes the development of learning tools which refers to the Thiagarajan 4-D model (1974) [14] which consists of four stages, namely define, design, develop, disseminate. . Learning tools developed using a realistic approach namely Learning Implementation Plans (RPP), Student Activity Sheets (LKS), Teacher Books, Student Books, Learning Outcomes of Mathematical Literacy Ability (THBKLM). The Development Model in this study is schematically illustrated in the following chart: 


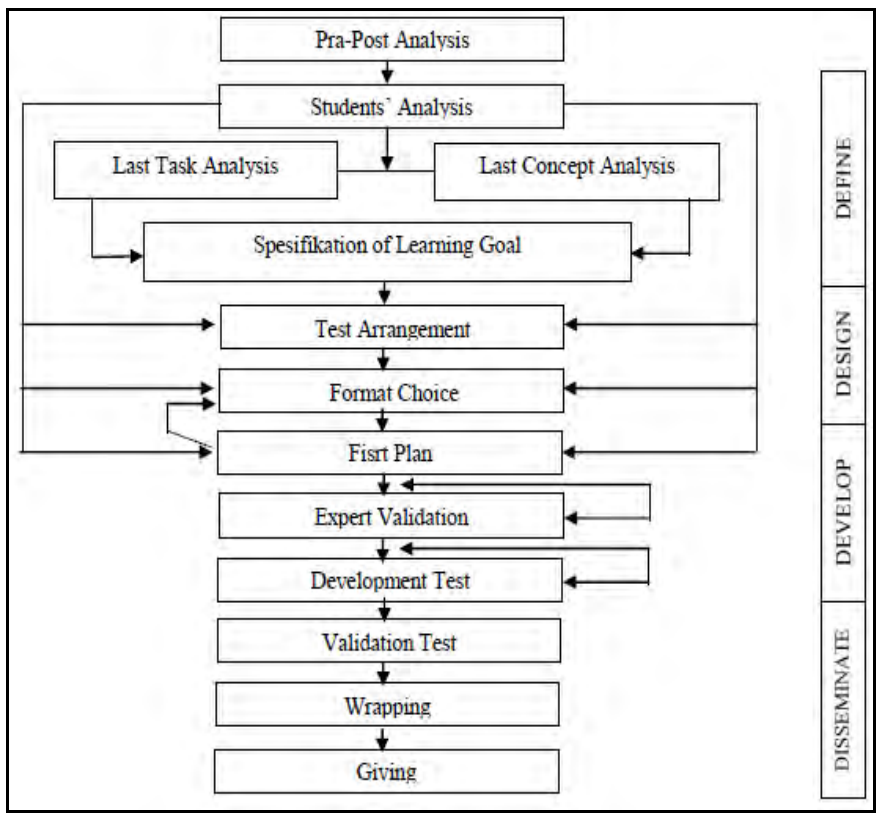

Fig I: DEVELOPMENT PROCEDURE OF 4-D MODEL

(SOURCE: ADAPTED FROM THIAGARAJAN 1974: 6-9)

\section{RESULTS AND DISCUSSION}

\section{Test 1}

The effectiveness of a realistic approach-based learning device is determined based on: (1) classical student learning completeness, ie $85 \%$ of students participating in THBKLM get a minimum score of 75; (2) the completeness of student learning goals reaches $75 \%$, and (3) $80 \%$ of students give a positive response to the developed learning tools, it can be seen in the following table:

\section{TABLE I - EFFECTIVENESS OF LEARNING DEVICES IN TEST I}

\begin{tabular}{|c|c|c|}
\hline Rated aspect & Achievement & Describtion \\
\hline $\begin{array}{c}\text { Classical student learning } \\
\text { completeness }\end{array}$ & $40.54 \%$ & Not complete \\
\hline $\begin{array}{c}\text { Complete learning } \\
\text { objectives }\end{array}$ & $71.87 \%$ & Not complete \\
\hline Positive student response & $91.5 \%$ & Complete \\
\hline
\end{tabular}

From the table above, it can be concluded that learning using learning tools developed based on a realistic approach in the first test was not effective.

\section{Test II}

The effectiveness of a realistic approach-based learning device is determined based on: (1) classical student learning completeness, ie $85 \%$ of students participating in THBKLM get a minimum score of 75 ; (2) the completeness of student learning goals reaches $75 \%$, and (3) $80 \%$ of students give a positive response to the developed learning tools, it can be seen in the following table:
TABLE 2 - EFFECTIVENESS OF LEARNING DEVICES IN TEST II

\begin{tabular}{|c|c|c|}
\hline Rated aspect & Achievement & Describtion \\
\hline $\begin{array}{c}\text { Classical student learning } \\
\text { completeness }\end{array}$ & $89.19 \%$ & Complete \\
\hline $\begin{array}{c}\text { Complete learning } \\
\text { objectives }\end{array}$ & $85.83 \%$ & Complete \\
\hline Positive student response & $94.54 \%$ & Complete \\
\hline
\end{tabular}

Based on the results of data analysis in test II, it is known that the realistic approach-based learning tools that have been developed have fulfilled the effective indicators set in terms of: (1) classical student learning completeness, ie $85 \%$ of students who take a mathematical literacy ability test get a minimum score of 75 From the results of data analysis of classical student learning completeness in test II, $89.19 \%$ of students managed to obtain a value of $\geq 75$. (2) The achievement of completeness of student learning goals was $75 \%$. From the results of data analysis, the completeness of students' learning objectives in the test II completeness of the student learning objectives reached $85.83 \%$. (3) A minimum of $80 \%$ of students give positive responses to the developed learning tools. From the results of the analysis of student response data in the second test positive responses obtained reached $94.54 \%$. So, the three effective indicators have been fulfilled, so it can be concluded that the realistic approachbased learning tools developed in the second test have been effective.

From this study, the following results were obtained:

a. Based on the results of an analysis of the improvement of students 'mathematical literacy skills in the I and II test showed that the average students' mathematical literacy ability in the first test was 71.33 , then increased to 85.83 in the second test. Thus, there is an increase in the average value of students' mathematical literacy abilities by 14.5 .

TABLE 3 - INCREASING STUDENTS' MATHEMATICAL LITERACY ABILITY

\begin{tabular}{|c|c|c|c|c|c|}
\hline \multirow{2}{*}{ Description } & \multicolumn{5}{|c|}{ Average } \\
\cline { 2 - 6 } & Ind. & Ind. & Ind. & Ind. & THB \\
& 1 & 2 & 3 & 4 & KLM \\
\hline Test I & 2.81 & 3.41 & 3.26 & 1.99 & 71.33 \\
\hline Test II & 3.52 & 3.58 & 3.63 & 3.00 & 85.83 \\
\hline Improvement & 0.71 & 0.17 & 0.36 & 1.01 & 14.5 \\
\hline
\end{tabular}

An increase in the average value of students' mathematical literacy skills is given in the following diagram. 


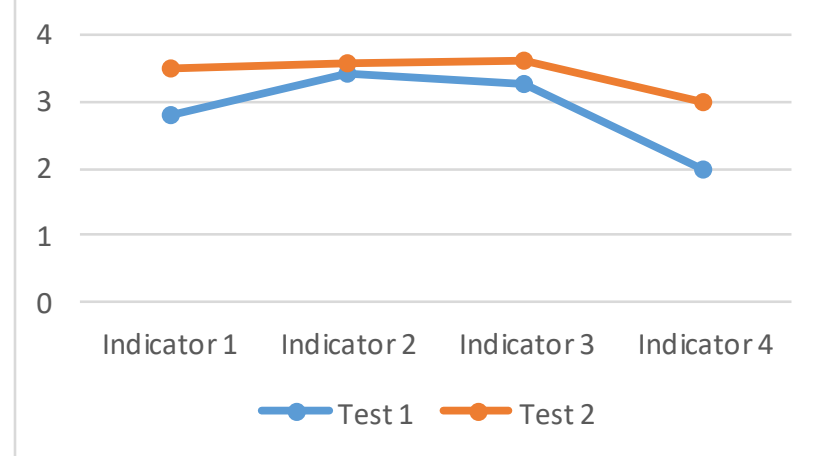

Fig 2: GRAPH FOR INCREASING STUDENTS' MATHEMATICAL LITERACY ABILITY

b. In determining the effectiveness of learning devices seen from three aspects, namely (1) classical student learning completeness, ie $85 \%$ of students who take a mathematical literacy test get a minimum score of $75 ;(2)$ completeness of student learning objectives $75 \%$; and (3) student responses, ie at least $80 \%$ of students give a positive response to the developed learning device.

TABLE 4 - Effectiveness of Learning Devices

\begin{tabular}{|c|c|c|}
\hline Indicator of Efektif & Test 1 & Test 2 \\
\hline Classical student learning completeness & $40.54 \%$ & $89.19 \%$ \\
\hline $\begin{array}{c}\text { Complete learning objectives } \\
\text { pembelajaran }\end{array}$ & $71.87 \%$ & $85.83 \%$ \\
\hline Positive student response & $91.5 \%$ & $94.54 \%$ \\
\hline
\end{tabular}

From the table above it can be concluded that in the test I the learning tools developed did not meet the three effective indicators, whereas in the second test the three effective indicators were fulfilled, so that the learning tools developed were included in the effective criteria

\section{CONCLUSION}

The conclusions of this study are:

a. The average mathematical literacy ability of students in the first test was 71.33, while in the second test it increased to 85.83 . Thus, it can be concluded that there is an increase in the average value of students' mathematical literacy skills after getting learning using a realistic approach-based learning tool, which is equal to 14.5 .

b. The completeness of the learning objectives of students in the first test reached $71.87 \%$, while in the second test reached $85.83 \%$; (c) $80 \%$ of students gave a positive response to the learning device developed. The response of students in the first test reached $91.5 \%$, while the second test reached $94.54 \%$.

\section{References}

[1] OECD. 2013. PISA 2012 Assesment and Analytical Framework: Mathematics, Raeding, Science, Problem Solving and Financial Literacy. Paris: OECD Publishing.

[2] Pusat Penilaian Pendidikan Balitbang Kemdikbud. 2012a. Determinants of Learning Outcomes TIMSS 2011: Final Report. Jakarta: Pusat Penilaian Pendidikan.

[3] Badan Penelitian dan Pengembangan, Kemdikbud. 2013. Laporan Studi Kajian Peserta Didik pada Tingkat Dasar dan Menengah. Jakarta: Badan Penelitian dan Pengembangan.

[4] Pusat Penilaian Pendidikan Balitbang Kemdikbud. 2012b. Kemampuan Membaca Siswa Kelas IV Sekolah Dasar di Provinsi Kalimantan Timur dan D.I. Yogyakarta. Jakarta: Pusat Penilaian Pendidikan.

[5] OECD. 2013. PISA 2012 Results: What Students Know and Can Do: Student Performance inMathematics, Reading and Science. (Volume 1) Paris: PISA- OECD Publishing.

[6] OECD. 2009. PISA 2009 Assessment Framework- Key Competencies I Reading, Mathematics and Science. Paris: OECD.

[7] A, Delyanti. 2014. Pengembangan Instrumen Literasi matematis Model PISA. Journal of Educational Research and Evaluation 3 (2) 74-79 ISSN 22552-64207.

[8] Wardono. 2014. The Realistic Learning Model with Character Education and PISA Assessment to Improve Mathematics Literacy. International Journal of Education and Research. 7(2): 361-372.

[9] H, Freudenthal. 1991. Revisiting mathematics education. Dordrecht: Kluwer Academic Publishers.

[10] K, Gravemeijer. 1994. Developing Realistic Mathematics Education. Utrecht: Freudental Institute.

[11] Trianto. 2009. Mendesain Model Pembelajaran Inovatif-Progresif. Jakarta: Kencana Prenada Media Grup

[12] P, Suparno. 2012. Peran Pendidikan dan Penelitian Terhadap Pembangunan Karakter Bangsa. Makalah Seminar Nasional dalam Rangka Dies Natalis ke 48 UNY.

[13] Hasratuddin. 2015. Mengapa Harus Belajar Matematika?. Medan: Perdana Publishing.

[14] S, Thiagarajan. dkk. 1974. Instructional Development for Training Teachers of Exceptional Children, A Source Book. Blomington: Center of Inovation on Teaching the Handicapped Minnepolis Indiana University. 